\title{
Grain Yield of Hybrid Rice Varieties as Influenced by Seed Rates under Aerobic Direct Seeded Situation
}

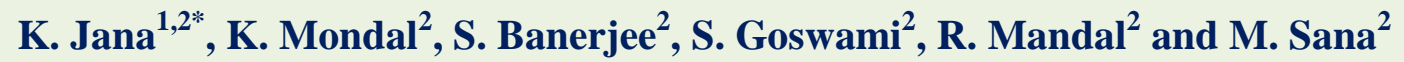 \\ ${ }^{1}$ AICRP on Forage Crops and Utilization, Bidhan Chandra Krishi Viswavidyalaya, \\ Kalyani - 741235, Nadia, West Bengal, India \\ ${ }^{2}$ Department of Agronomy, Faculty of Agriculture, Bidhan Chandra Krishi Viswavidyalaya, \\ Mohanpur - 741252, Nadia, West Bengal, India \\ *Corresponding author
}

\section{Keywords}

Hybrid rice varieties, HYV, Seed rates, Grain yield and aerobic direct seeded situation

\section{Article Info}

Accepted: 20 September 2018 Available Online: 10 October 2018

A B S T R A C T

Rice is an important staple food crop of the world. Aerobic rice system is a new way of growing rice that needs less water than low land rice. It is grown like an upland crop (maize, wheat, Oats etc.) in soil, which is un-puddled, non-flooded or saturated. On the basis of this fact an experiment was conducted during kharif season of 2013 and 2014 at Rice Research Station, Bankura, West Bengal, India. The soil of experimental field was sandy loam in texture with medium in fertility status. This experiment was laid out in a split-plot design (SPD) with three replications and compared two factors (4 rice varieties and 4 different seed rates) to find out the optimum seed rate for different rice varieties (HYV and hybrid) under aerobic un-puddled condition. Recommended fertilizer dose (RFD) was $\mathrm{N}, \mathrm{P}_{2} \mathrm{O}_{5}, \mathrm{~K}_{2} \mathrm{O} @ 80,40,40 \mathrm{~kg} \mathrm{ha}^{-1} . \mathrm{ZnSO}_{4} @ 25 \mathrm{~kg} \mathrm{ha}^{-1}$ was applied as basal. Pendimethalin (PE) @ $1.0 \mathrm{~kg}$ a.i. ha ${ }^{-1}$ at 1 day after sowing (DAS) and 2, 4-D Na salt (80 WP)@0.08 kg a.i. ha ${ }^{-1}$ at 20 DAS was applied. One hand weeding was done at 50 DAS. Direct seeding was done at row spacing of $20 \mathrm{~cm}$ with continuous sowing. Four rice varieties; $\mathrm{V}_{1}$ - Puspa (IET 17509), $\mathrm{V}_{2}$ - Vandana, $\mathrm{V}_{3}$ - DRRH-3 and $\mathrm{V}_{4}-$ PAC-837 were randomly allotted in the three main plots; while four levels of seed rates $\left(S_{1}-15, S_{2}-25\right.$, $\mathrm{S}_{3}-35$ and $\mathrm{S}_{4}-45 \mathrm{~kg} \mathrm{ha}^{1}$ ) were randomly allotted in the four sub plots of each main plot. The experimental results revealed that varieties (HYV and hybrid) and seed rates have marked influence on yield attributes and yield of aerobic rice. Aerobic rice yield increased significantly as the seed rate increased from 15 to $25 \mathrm{~kg} \mathrm{ha}^{-1}$. There is significant increase in yield with increase in seed rate upto $25 \mathrm{~kg} \mathrm{ha}^{-1}$. The results established that seed rate of $25 \mathrm{~kg} \mathrm{ha}^{-1}$ was promising for realizing best aerobic rice yield. Among the varieties tested, hybrids out yielded the high yielding varieties (HYV). Hybrid rice variety DRRH-3 proved the best. The yield increase was ascribed to concomitant increase in panicle number and panicle weight. DRRH-3 has yielded highest grain yield (4.19 t/ha) in aerobic situation during kharif, 2013 and 2014.

\section{Introduction}

Rice (Oryza sativa L.) is an important cereals crop and grown across the world. By the end of $21^{\text {st }}$ Century, the earth's climate is predicted to warm by an average of $2-4^{0} \mathrm{C}$ (IPCC, 2007) due to anthropogenic and natural factors (Eitzinger et al., 2010). Rice cultivation is a 
water intensive enterprise. However, lowland rice fields have relatively high water requirements and their sustainability is threatened by increasing water shortages (Bouman and Tuong, 2001). Rice consumes more than $50 \%$ of the water used for irrigation in Asia (Barker et al., 1999). Aerobic rice system is the method of cultivation, where the rice crop is established by direct seeding (dry or water-soaked seed) in un-puddle field and non-flooded field condition (Jana, 2012a). The usual way of planting aerobic rice is the same as we would plant the other cereal crops like wheat, oats or maize by direct seeding. There is no need of raising of seedling in nursery bed and puddle operation in the main field (Jana, 2012b). Compared with flooded lowland rice, aerobic rice requires $30-50 \%$ less water (Bouman et al., 2005). Supplementary irrigation is applied in aerobic rice system of cultivation as and when required and can be supplied in the same way as to any upland cereals crops like maize, wheat (Bouman et al., 2005; Wang et al., 2002). Aerobic rice system in un-puddled situation during boro season also by using short duration rice varieties is possible through good agronomic management practices and it is the rice for future (Jana, 2013). Hence, shifting gradually from traditional rice production system to growing rice in aerobic condition especially in upland and mid-upland situation during kharif season can mitigate the problem. Information of optimum seed rates with different rice varieties specifically hybrid rice varieties for maximizing grain yield of aerobic rice under aerobic situation is scanty. Therefore, an attempt was made for achieving maximum production of grain yield of aerobic hybrid rice in aerobic direct seeded situation during kharif season under changed climate.

\section{Materials and Methods}

The research-based information on the seed rate and hybrid rice varieties of aerobic direct seeded rice system is very meagre. So, on the basis of this fact, a field experiment on "Grain yield of hybrid rice varieties as influenced by seed rates under aerobic direct seeded situation" was conducted during kharif season of 2013 and 2014 at Rice Research Station, Bankura, West Bengal, India on sandy loam soil. This experiment was laid out in a splitplot design with three replications and compared two factors (four rice varieties and four different seed rates) to find out the optimum seed rate for different rice varieties (HYV and hybrid) under aerobic un-puddled condition. Four rice varieties; $\mathrm{V}_{1}$ - Puspa (IET 17509), $V_{2}$ - Vandana, $V_{3}$ - DRRH-3 and $V_{4}$ PAC-837 were randomly allotted in the three main plots; while four levels of seed rates $\left(\mathrm{S}_{1}\right.$ $15, S_{2}-25, S_{3}-35$ and $S_{4}-45 \mathrm{~kg}$ ha $\left.{ }^{1}\right]$ were randomly allotted in the four sub plots of each main plot. The plot size was $4 \mathrm{~m}$ X $3 \mathrm{~m}$.

\section{Fertilizer management}

The recommended dose was $\mathrm{N}, \mathrm{P}_{2} \mathrm{O}_{5}, \mathrm{~K}_{2} \mathrm{O}$ @ $80,40,40 \mathrm{~kg} \mathrm{ha}^{-1} .25 \%$ of recommended dose of nitrogen, full dose of phosphorus, $75 \%$ of potash and $\mathrm{ZnSO}_{4} @ 25 \mathrm{~kg} \mathrm{ha}^{-1}$ was applied as basal. Remaining dose of $\mathrm{N}$ in two splits was applied. 50\% $\mathrm{N}$ at active tillering stage and $25 \% \mathrm{~N}$ along with $25 \%$ Potash at Panicle initiation stage were applied.

\section{Weed Management}

Pendimethalin (PE) @ $1.0 \mathrm{~kg}$ a.i. ha ${ }^{-1}$ at 1 day after sowing (DAS) and 2, 4-D Na salt (80 WP)@ $0.08 \mathrm{~kg} a . i . \mathrm{ha}^{-1}$ at 20 DAS was applied. One hand weeding was done at 55 DAS.

\section{Characteristics of soil}

The characteristics of red and lateritic soils are poor in organic matter content, available phosphate and in bases. The upland soils are mostly eroded with a very low water holding 
capacity. Crust formation in the upland soils is serious problem. This experiment was conducted in upland. The texture of experimental soil was sandy loam with slightly acidic in nature ( $\mathrm{pH}: 5.5), 0.14 \mathrm{ds} \mathrm{m}^{-1}$ EC, organic carbon $0.46 \%$, available $\mathrm{P}_{2} \mathrm{O}_{5} 51$ $\mathrm{kg} \mathrm{ha}^{-1}$ and available $\mathrm{K}_{2} \mathrm{O} 164 \mathrm{~kg} \mathrm{ha}^{-1}$.

Observation on yield parameters and yield was recorded. Data was statistically analysed. The $5 \mathrm{~m}^{2}$ area in the middle of each plot was harvested for recording grain yield.

Ten rice hills outside the harvested area were selected and harvested separately for recording panicle weight. The number of matured panicles per $\mathrm{m}^{2}$ area in the middle of each plot was recorded.

\section{Results and Discussion}

Seed rate and rice varieties (hybrid and HYV) are one of the most important factors that determine the grain yields of aerobic direct seeded rice. The growth, development and grain yield of aerobic rice are greatly influenced by the seed rate and variety which is cultivated under field condition.

\section{Matured Panicles}

The experimental results revealed that in the main plot treatment $\mathrm{V}_{3}$ i.e. hybrid variety DRRH 3 significantly recorded more number of matured panicles $\mathrm{m}^{-2}$ (429) in pooled value. Lowest number of matured panicles $\mathrm{m}^{-2}$ (357 as pooled value) was obtained with the $\mathrm{V}_{2}$ i.e. HYV Vandana in main plot. Similar trend was noticed during the kharif 2013 and kharif 2014 (Table 1). On the other hand, among the seed rate treatments, the treatment $\mathrm{S}_{2}$ i.e. seed rate @ $25 \mathrm{~kg} \mathrm{ha}^{-1}$ recorded significantly more number of matured panicles $\mathrm{m}^{-2}$ (425) in pooled value (Table 1). This might due to an optimum plant population, was obtained in respective plots with special reference to row spacing $(20 \mathrm{~cm})$. The treatment combination of $\mathrm{V}_{3}$ (hybrid variety DRRH-3) and $\mathrm{S}_{2}$ (seed rate@25 kg ha ${ }^{-1}$ ) recorded the highest number of matured panicles $\mathrm{m}^{-2}$ (466) in pooled analysis (Table 2). This could be attributed with using both the hybrid variety DRRH-3 and seed rate @ $25 \mathrm{~kg} \mathrm{ha}^{-1}$ and as a result of higher uptake and recovery of applied nutrients.

It was noticed that more number of matured panicles $\mathrm{m}^{-2}$ was recorded with the treatment $\mathrm{V}_{3}$ (i.e. hybrid rice variety DRRH-3), which reflected on the achieving maximum grain yield of aerobic direct seeded rice.

\section{Panicle weight}

Regarding panicle weight, it was significantly influenced by the levels of both varieties (HYV and hybrid) and seed rate in pooled analysis. Among the sub plot the highest panicle weight $(2.19 \mathrm{~g})$ was recorded with treatment $S_{1}$ (seed rate @ $15 \mathrm{~kg} / \mathrm{ha}$ ) and it was statistically at par with treatment $S_{2}$ (seed rate @ $25 \mathrm{~kg} / \mathrm{ha})$. Lowest value $(1.77 \mathrm{~g})$ was obtained with $\mathrm{S}_{4}$ (seed rate @ $45 \mathrm{~kg} / \mathrm{ha}$ ) in pooled analysis (Table 1). This might be due to closer spacing, which hampers intercultural operations and increases competition among the rice plants for nutrients, air, light and water; which results in weaker plants, reduced panicle weight and mutual shading thus favours more straw yield than grain yield.

\section{Grain yield}

The treatment $\mathrm{V}_{3}$ i.e. DRRH-3 (hybrid) recorded highest gain yield $\left(4.19 \mathrm{t} \mathrm{ha}^{-1}\right)$ and it was statistically at par with $\mathrm{V}_{4}$ i.e. PAC-837 (hybrid) which yielded grain yield of $3.94 \mathrm{t} \mathrm{ha}^{-}$ 1 in aerobic direct seeded situation during kharif season (Table 1). Lowest grain yield $\left(3.53 \mathrm{t} \mathrm{ha}^{-1}\right.$ ) was obtained at treatment $\mathrm{V}_{2}$ i.e. Vandana (HYV) in aerobic situation in pooled analysis. 
Table.1 Number of matured panicles $\mathrm{m}^{-2}$, panicle weight and grain yield of hybrid rice varieties as influenced by seed rate in aerobic direct seeded situation during kharif season (pooled value)

\begin{tabular}{|c|c|c|c|}
\hline Parameters & No. of Panicle $\mathrm{m}^{-2}$ & Panicle wt. (g) & Grain yield $\left(\mathrm{t} \mathrm{ha}{ }^{-1}\right)$ \\
\hline \multicolumn{4}{|l|}{ Varieties } \\
\hline $\mathrm{V}_{1}$ (Puspa) & 377 & 1.83 & 3.68 \\
\hline $\mathbf{V}_{2}$ (Vandana) & 357 & 1.75 & 3.53 \\
\hline $\mathrm{V}_{\mathbf{3}}$ (DRRH-3) & 429 & 2.21 & 4.19 \\
\hline $\mathrm{V}_{4}(\mathrm{PAC}-837)$ & 393 & 2.10 & 3.94 \\
\hline S.Em ( \pm$)$ & 3.6 & 0.11 & 0.13 \\
\hline CD (0.05) & 11.2 & 0.34 & 0.42 \\
\hline C.V. $(\%)$ & 5.4 & 10.48 & 9.84 \\
\hline \multicolumn{4}{|c|}{ Seed rate (kg/ha) } \\
\hline$S_{1}(15)$ & 339 & 2.19 & 3.50 \\
\hline$S_{2}(25)$ & 425 & 2.03 & 4.15 \\
\hline$S_{3}(35)$ & 407 & 1.91 & 3.94 \\
\hline$S_{4}(45)$ & 385 & 1.77 & 3.74 \\
\hline S.Em ( \pm$)$ & 22.8 & 0.08 & 0.12 \\
\hline CD $(0.05)$ & 70.7 & 0.24 & 0.37 \\
\hline Expt. Mean & 389 & 1.97 & 3.83 \\
\hline
\end{tabular}

Table.2 Interaction effects between rice varieties (HYV and hybrid) and seed rate on number of matured panicles $\mathrm{m}^{-2}$, panicle weight and grain yield in aerobic direct seeded situation during kharif season (pooled value)

\begin{tabular}{|c|c|c|c|c|}
\hline Varieties & Seed rate & No. of Panicle $\mathrm{m}^{-2}$ & Panicle wt. (g) & Grain yield $\left(\mathrm{t} \mathrm{ha}^{-1}\right)$ \\
\hline \multirow{4}{*}{$\mathrm{V}_{1}$} & $\mathrm{~S}_{1}$ & 329 & 2.03 & 3.32 \\
\hline & $\mathrm{S}_{2}$ & 408 & 1.85 & 4.02 \\
\hline & $\mathrm{S}_{3}$ & 395 & 1.79 & 3.83 \\
\hline & $\mathrm{S}_{4}$ & 377 & 1.66 & 3.53 \\
\hline \multirow[t]{4}{*}{$\overline{\mathbf{V}_{2}}$} & $\mathrm{~S}_{1}$ & 315 & 1.92 & 3.25 \\
\hline & $\mathrm{S}_{2}$ & 392 & 1.77 & 3.83 \\
\hline & $\mathrm{S}_{3}$ & 370 & 1.72 & 3.62 \\
\hline & $\mathrm{S}_{4}$ & 350 & 1.60 & 3.42 \\
\hline \multirow[t]{4}{*}{$\overline{V_{3}}$} & $\mathrm{~S}_{1}$ & 374 & 2.44 & 3.82 \\
\hline & $\mathrm{S}_{2}$ & 466 & 2.32 & 4.55 \\
\hline & $\mathrm{S}_{3}$ & 451 & 2.12 & 4.32 \\
\hline & $\mathrm{S}_{4}$ & 425 & 1.97 & 4.08 \\
\hline \multirow[t]{4}{*}{$\mathrm{V}_{4}$} & $\mathrm{~S}_{1}$ & 341 & 2.36 & 3.61 \\
\hline & $\mathrm{S}_{2}$ & 433 & 2.19 & 4.21 \\
\hline & $\mathrm{S}_{3}$ & 411 & 1.99 & 4.01 \\
\hline & $\mathrm{S}_{4}$ & 386 & 1.85 & 3.92 \\
\hline \multicolumn{5}{|l|}{$\mathrm{CD}(\mathbf{0 . 0 5})$} \\
\hline \multicolumn{2}{|l|}{ V at same $\mathbf{S}$} & 43 & 0.58 & 1.38 \\
\hline \multicolumn{2}{|c|}{ S at same $V$} & 40 & 0.52 & 1.25 \\
\hline
\end{tabular}


Chart.1 Graphical representation of grain yield as influenced by varieties

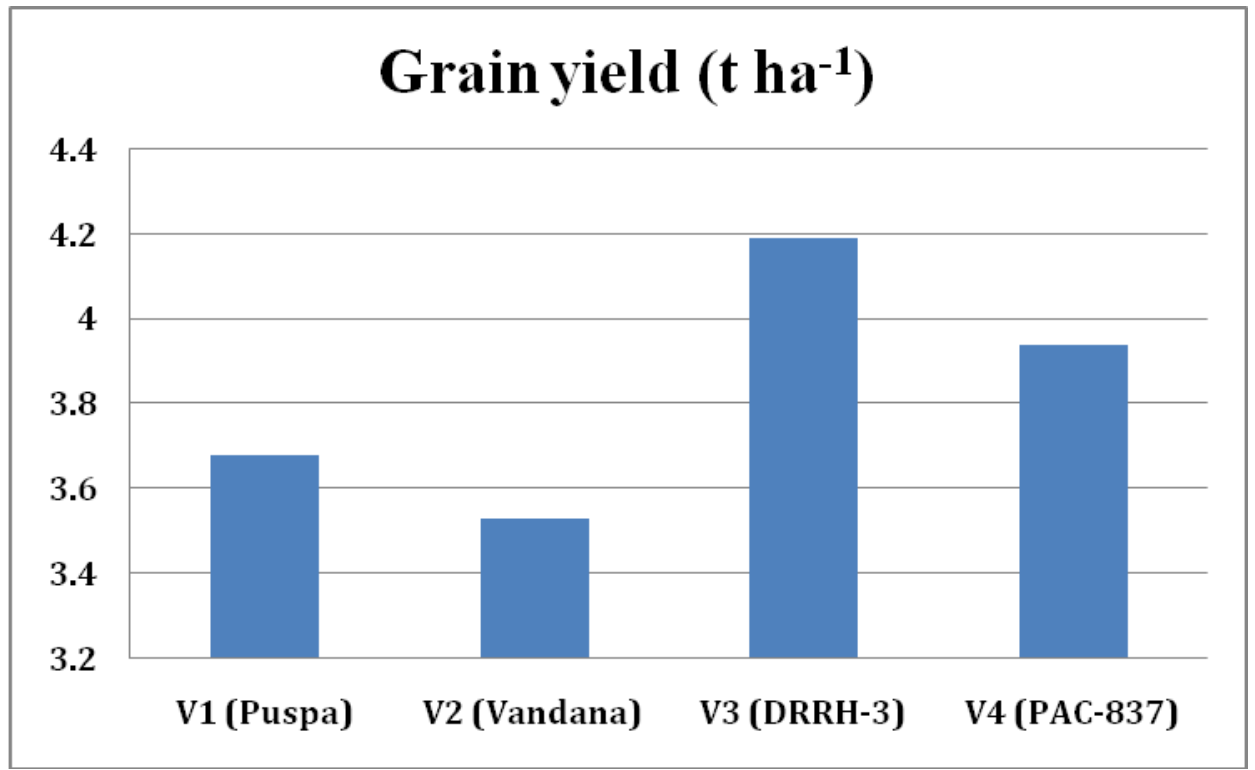

Chart.2 Graphical representation of grain yield as influenced by seed rate $(\mathrm{kg} / \mathrm{ha})$

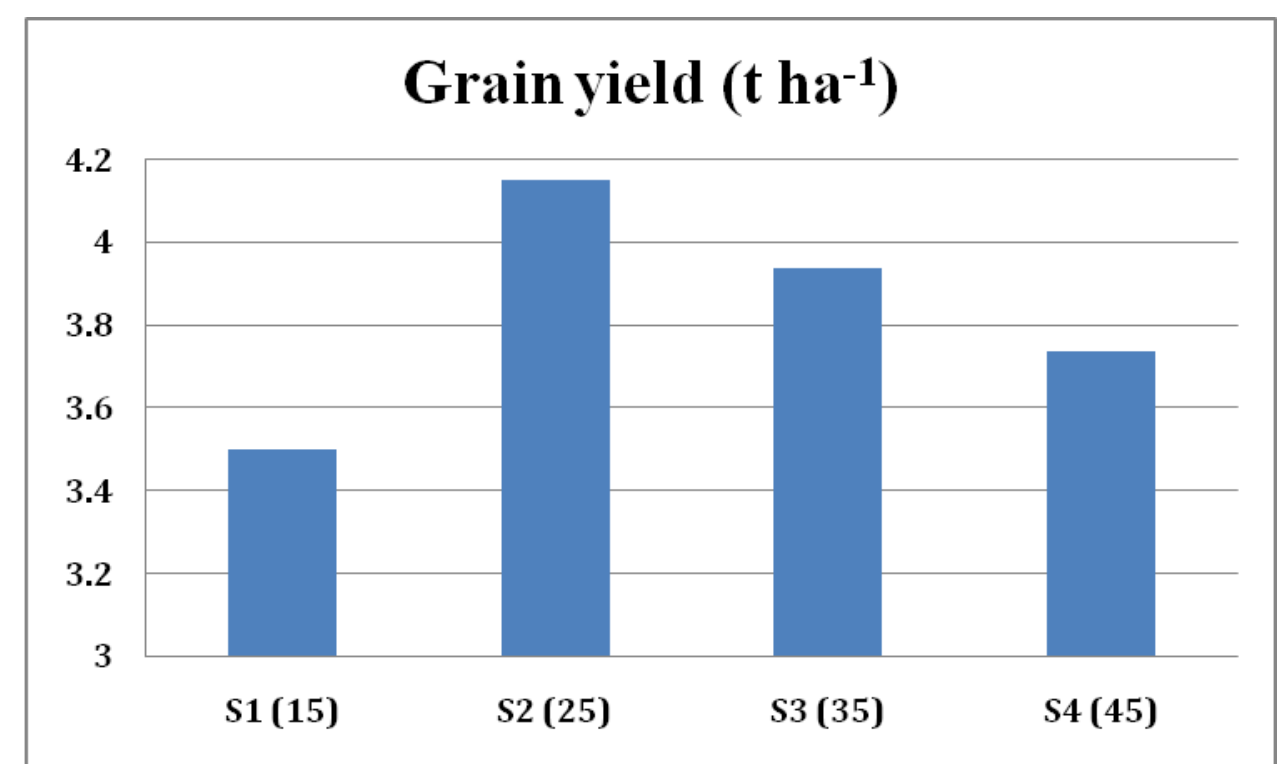

This might be due to better root growth and proliferation and also opportunity to extract water and nutrients both from larger soil profile area, which in turn must have improved synthesis and translocation of metabolites to various reproductive structures of rice plant and better distribution of it into grain would always results in higher grain yield in case of hybrid rice. Another reason is that the maximum number of matured panicles $\mathrm{m}^{-2}$ (429 as pooled value) was obtained from DRRH-3 rice hybrid. Higher grain yield was obtained from DRRH-3 due to increased number of effective tillers $\mathrm{m}^{-2}$.

On the other hand among the seed rate treatments in sub plot highest grain yield $\left(4.15 \mathrm{t} \mathrm{ha}^{-1}\right.$ ) was recorded at $\mathrm{S}_{2}$ (seed rate @ 
$25 \mathrm{~kg} / \mathrm{ha}$ ) treatment during kharif season as pooled value and lowest value $\left(3.50 \mathrm{t} \mathrm{ha}^{-1}\right)$ was obtained at treatment $S_{1}$ (seed rate @ 20 $\mathrm{kg} / \mathrm{ha})$. The result is in agreement with the findings of Mankotia et al., (2005) and they reported that optimization of seed rate is most important factor for the overall improvement of productivity of rainfed upland rice. It was also observed that further increase in seed rate upto $45 \mathrm{~kg} / \mathrm{ha}$ grain yield was decreasing. Decreased in grain yield may be due to increase in competition among the rice plants for water, nutrients, air and light etc., which resulted in weaker plants and ultimately produced lower grain yield, when used higher seed rate. A despite improvement in weed management, higher seeding rate $\left(35 \mathrm{~kg} \mathrm{ha}^{-1}\right)$ may exacerbate problems like lodging (Bond et al., 2005), insect and diseases infestation (Tan et al., 2000) and rat damaged that harm the crop yield. Another reason is that high seed rate ( 35 and $45 \mathrm{~kg} \mathrm{ha}^{-1}$ ) may bring about problem of mutual shading and intra-specific competition for below-ground resources. At low seeding rate $\left(15 \mathrm{~kg} \mathrm{ha}^{-1}\right)$ rice crop plants take more time to close their canopy which encourages the weed growth. The results are in agreement with the findings of Hari et al., (1997), Rajendra and Veeraputhiran (1999) and they reported that low seed rate resulted high seeding quality and leaf area per plant. On the other hand, treatment $S_{2}$ i.e. seed rate @ $25 \mathrm{~kg} \mathrm{ha}^{-1}$ (medium seed rate) helps in suppression of weed population as well as produced maximum of number of matured panicles $\mathrm{m}^{-2}$ and ultimately produced highest grain yield $\left(4.15 \mathrm{t} \mathrm{ha}^{-1}\right)$ of aerobic direct seeded rice. The results are in agreement with the findings of El-Kallawy (2002) and he studied the effect of different seeding rates and found that low seed rate has significantly raised the seedling vigour where it gave the highest values of leaf area per plant and leaf number per stem. The treatment combination of $\mathrm{V}_{3}$ (DRRH-3: hybrid) and $\mathrm{S}_{2}$ (seed rate @ $25 \mathrm{~kg} \mathrm{ha}^{-1}$ ) recorded the highest grain yield
(4.55 $\mathrm{t} \mathrm{ha}^{-1}$ ) of aerobic direct seeded rice (Table 2). The maximum benefit in respect of rice grain yield can be obtained where planting is done with proper seed rate.

The results of this experiment established that hybrid DRRH-3 and seed rate @ $25 \mathrm{~kg} \mathrm{ha}^{-1}$ were promising for realizing best grain yield $\left(4.55 \mathrm{t} \mathrm{ha}^{-1}\right)$ in aerobic direct seeded situation during kharif. In recent years, uneven distribution, erratic pattern and irregular rains due to climate change (global warming) has limited rice cultivation. Aerobic rice cultivation is a sustainable rice production methodology for immediate future to address water scarcity and environmental safety arising due to global warming. Aerobic rice is the rice for the future.

\section{Acknowledgement}

The authors would like to thanks Dr. P. K. Maity, Additional Joint Director of Agriculture (Research); Mr. S. R. Patra, Director of Agriculture, Writers' Building, Kolkata -1 and Prof. B. K. Mandal, retired Professor and former Head, Prof. A. M. Puste, Prof. S. B. Goswami, Prof. K. Brahmachari, Prof. B. C. Patra, Department of Agronomy, Bidhan Chandra Krishi Viswavidyalay, Mohanpur, Nadia, West Bengal, India for their valuable guidance and encouragement during the period of this research programme.

\section{References}

Barker, R., Dawe, D., Tuong, T. P., Bhuiyan, S.I. and Guerra, L.C. 1999. The outlook of water resources in the year 2020: Challenges for research on water management in rice production. Assessment and orientation towards the $21^{\text {st }}$ century. : 96-109.

Bond, J.A., Walker, T.W., Bollich, P.K., Koger, C.H. and Gerard, P. 2005. Seeding rates for stale seedbed rice 
production in the mid-southern United States. Agron. J. 97: 1560-1563.

Bouman, B. A. M. and Tuong, T. P. 2001. Field water management to save water and increase its productivity in irrigated rice. Agricultural Water Management 49 (1): 11-30.

Bouman, B. A. M., Peng, S. Castaneda, A. R. and Visperas, R.M. 2005. Yield and water use of irrigated tropical aerobic rice systems. Agricultural Water Management 74: 87-105.

Eitzinger, J., Orlandini, S., Stefanski, R. and Naylor, R.E.L. 2010. Climate Change and agriculture: Introductory editorial. Journal of Agricultural Sciences, Cambridge 148: 499-500.

El-Kallawy, WHM. 2002. Effect of some agronomic practices on growth and yield of rice. M.Sc. Thesis, Agron. Dept. Fac. Agric. Kafr EL-Sheikh, Tanta Univ.

Hari, O.M., Katyal, S.K. and Dhiman, S.K. 1997. Growth analysis of hybrid rice as influenced seeding density in nursery and nitrogen levels. Haryana Agric. Uni. J. Res. 27 (2): 127-130.

Jana, K. 2012a. Effect of nitrogen levels and weed management practices on grain yield of aerobic rice cultivation system. Green farming, 3 (6): 687-689.
Jana, K. 2012b. Aerobic Rice System towards Tackling Climate Change. SATSA MUKHAPATRA - Annual technical issue, 16: 81-88.

Jana, K. 2013. Evaluation of aerobic rice system during boro season under red and laterite zone of West Bengal. Crop Research - An International Journal, 45 (No. 1, 2 \& 3): 20-23.

Mankotia, B.S. and Shekar, J. 2005. Studies on Integrated nutrient supply and seed rate for direct seeded rianfed upland rice in mid hills of Himachal Pradesh. Journal of Rice Research, 2 (1): 23-26.

Rajendra, K. and Veeraputhiran, R. 1999. Effect of seed rates and nitrogen levels on hybrid rice (Oryza sativa). Madras Agric. J. 86 (7-9): 459-460.

Tan, P.S., Khuong, T.Q. and Hoai, N.T. 2000. Low cost technologies for rice production in the ekong delta. In: Proceedings of the Paper presented at National Workshop on September 2123. Ho Chi Minh City, Vietnam, pp. 14.

Wang, H., Bouman, B. A. M., Dule, Z., Wang, C. and Moya, P. F. 2002. Aerobic rice in northern China: opportunities and challenges. Waterwise rice production. Proceedings of the International Workshop on water-wise Rice Production, IRRI, April. 8-11, 2002, Los Banos, Philippines: 143-154.

\section{How to cite this article:}

Jana, K., K. Mondal, S. Banerjee, S. Goswami, R. Mandal and Sana, M. 2018. Grain Yield of Hybrid Rice Varieties as Influenced by Seed Rates under Aerobic Direct Seeded Situation. Int.J.Curr.Microbiol.App.Sci. 7(10): 2839-2845. doi: https://doi.org/10.20546/ijcmas.2018.710.330 